\title{
Examples of National and Transnational Cinema: Akira Kurosawa’s Yojimbo and Sergio Leone’s A Fistful of Dollars
}

\author{
Flavia Brizio-Skov \\ University of Tennessee, Knoxville, USA
}

\begin{abstract}
The term transnational originated in the historical field when, in the late 1990s, Ian Tyrrell wrote a seminal essay entitled “What is Transnational History?” and changed the course of the academic discipline, claiming that studying the history of a nation from inside its borders was outmoded because the study of history concerns the movements of peoples, ideas, technologies, and institutions across national boundaries. The study of cross-national influences and the focus on the relationship between nation and factors beyond the nation spilled over into many other fields, especially into cinematic studies. Today transnational refers to the impossibility of assigning a fixed national identity to much cinema, to the dissolution of any stable connection between film's place of production and the nationality of its makers and performers. Because there is a lot of critical debate about what constitutes national and transnational cinema, the study of international remakes is a promising method to map the field with some accuracy. This essay will analyze the journey from Hammett's novel to Kurosawa's film and then to Leone’s western, and will demonstrate how the process of adaptation functions and what happens to a "text” when it becomes transnational and polysemic. Because Leone is the creator of the Italian western, the one who initiated the cycle that was copied many times over for a decade, we must look at A Fistful of Dollars as a prototype, a movie that when dissected can shed light on the national-transnational dichotomy of the spaghetti western. However, before studying the prototype, we must look at the complex history of the origin of the first spaghetti western, taking into account that A Fistful of Dollars was “transcoded” by Leone from Kurosawa’s Yojimbo (1961) that derived his script from Dashiell Hammett’s Red Harvest (1929).
\end{abstract}

Keywords: national and transnational cinema, adaptation from literature to screen, international remakes, transculturization, permutation, reappropriation, reinterpretation

\section{Introduction}

In the complex debate about national and transnational cinema, the study of international remakes is a promising method to map the field with some accuracy ${ }^{1}$. When dealing with remakes, we must remember that some important modifications occur. It is well known that the film industry has been operated on a transnational basis since its beginning, because movies are often co-production and are made to be distributed

Flavia Brizio-Skov, Ph.D. in Comparative Literature, Professor, Modern Foreign Languages and Literatures, University of Tennessee.

Correspondence concerning this article should be addressed to MFLL-701 McClung Tower, University of Tennessee, Knoxville, TN 37996-0470.

${ }^{1}$ In the course of this essay I will show that Sergio Leone's A Fistful of Dollars is not a remake of Kurosawa's Yojimbo; however, for working purposes in the incipit of this essay I use the word "remake" as an umbrella term. 
beyond national borders for economic gain. As a consequence, any film is potentially a product destined to travel abroad. However, remakes or adaptations in all their variations, from novel to screen, from film to film, from play to screen and so on, imply a process of transculturization, reappropriation, reinterpretation and permutation. $^{2}$ As Linda Hutcheon points out, adaptation “...is repetition but without replication, bringing together the comfort of the ritual and recognition with the delight of surprise and novelty... it involves both memory and change, persistence and variation."3

If remaking a film implies, as Hutcheon reminds us, sameness through alterity, traveling stories—films in our case-adapt to local culture the same way as a virus, and in doing so they change, and in this way they keep themselves alive, they rejuvenate themselves, they evolve and mutate to fit new times and places, changing with each repetition. ${ }^{4}$

One of the best known cases of adaptation occurred between Akira Kurosawa's Yojimbo (1961) and Sergio Leone's A Fistful of Dollars (1964). Kurosawa derived the script of Yojimbo, a samurai story, from an American novel, Red Harvest (1929) by Dashiell Hammett (1894-1961). A Fistful of Dollars (1964), the prototype of the so-called spaghetti westerns, was "transcoded" by Sergio Leone from the Japanese film. The history of Leone's film proves not only that cinema is potentially transnational, but also shows that "cultural formations are invariably hybrid and impure." As we all know, the original story emigrated from the USA to Japan and from novel to screen, crossing genres. The story was transformed from a detective novel into a samurai film, then the film traveled from Japan to Italy where Leone translated it into his "local idiom”, with surprising results, and finally Leone's film traveled back to the United States in 1967. The enormous worldwide success of A Fistful of Dollars proves that the iconoclastic, violent and rebellious message of the film was well received by different audiences and triggered the birth of a new type of western. ${ }^{6}$ By the time, his trilogy was distributed internationally, Leone had become an established icon of world cinema and his films influenced directly and indirectly American western directors. ${ }^{7}$ Analyzing the journey from Hammett's novel to

\footnotetext{
2 Andrew Higson, in "The limiting imagination of national cinema," claims that "the meanings that an audience reads into a film are heavily dependent on the cultural context in which they watch it" (in Transnational Cinema, Elizabeth Ezra and Terry Rowden, eds. New York: Routledge, 2006, p. 19). A movie distributed abroad, according to Higson, will have three possible outcomes: "cultural imperialism" with liberating effects on the indigenous culture; negative effects corrupting the local culture, or, ultimately, the film will be interpreted according to an "indigenous' frame of reference," in the sense that it will be translated into the local idiom.

3 See Linda Hutcheon, A Theory of Adaptation. New York: Routledge, 2006, pp. 170-177.

${ }^{4}$ Ibidem, p. 173. Most theories of adaptations consider the story or the novel the common denominator of adaptation, following Linda Hutcheon in A Theory of Adaptation, I consider adaptation as a theoretical term that comprises many types of adaptations.

${ }^{5}$ See Transnational Cinema, Elizabeth Ezra and Terry Rowden, eds. London: Routledge, 2006, p. 19. We are aware that Leone’s film was not the first Italian western. Giorgio Ferroni's Il fanciullo del West dates back to 1942; Mario Amendola's Il terrore dell'Oklahoma was released in 1959; Caiano's well-known Duello nel Texas in 1963. Even in 1964, release year of A Fistful of Dollars, a number of westerns were released in earlier months. A chapter wholly dedicated to pre-Leone western films can be found in Matteo Mancini, Spaghetti Western, vol. 1 (Ed. Il Foglio, 2012). However, Leone established new conventions and popularized the Italian western, his films launched the "spaghetti phenomenon" and started a filone that lasted about a decade and produced 493 films. Il fanciullo del West and others were often tired reworkings of American formulas. For the importance of Leone as creator of the "filone" see Christopher Frayling, Spaghetti Westerns. London: I.B. Tauris, 1998, and Sergio Leone: Something to do with Death. London: Faber and Faber, 2000, and Christian Uva Sergio Leone. Il cinema come favola politica. Roma: Ente dello Spettacolo, 2013.

${ }^{6}$ For the fortune of the spaghetti western see Christopher Wagstaff's "A forkful of Westerns: industry, audiences and the Italian Western,” in Richard Dyer and Ginette Vincendau (eds.), Popular European Cinema. London: Routledge, 1992.

7 Leone's western trilogy includes: A Fistful of Dollars (1964), For a Few Dollars More (1965), and The Good, the Bad and the Ugly (1966). A Fistful of Dollars was distributed in the USA only in 1967 because of a legal battle with Toho Films, Kurosawa's studio that distributed Yojimbo. See Christopher Wagstaff's "Italian genre films in the world market," in Geoffrey Nowell-Smith and Stephen Ricci, eds. Hollywood and Europe: Economics, Culture, National Identity 1945-95. London: British Film Institute, 1998.
} 
Kurosawa's film and then to Leone's western, I will demonstrate how the process of adaptation functions and what happens to a "text" when it becomes transnational and polysemic.

\section{The National: The Hybrid Genres}

Since the 1920s, Italy has had a long history of American cultural colonization; from the time of Rudolph Valentino, the national market had been dominated by Hollywood imports. The impact of a brief hiatus between 1938-1945, during which foreign films (except German films) disappeared from the Italian screen, was quickly lost amidst the large backlog of American films that the Allied forces dumped on the national circuit from 1945 on. $^{8}$ As is now commonly recognized, the dominance of American cinema was motivated by geopolitical and ideological reasons: Italy was in the center of the Mediterranean and had a strong Communist Party. After World War II, the Americans helped the Christian Democrats gain power so as to prevent any possible defection towards Communism and poured a lot of money into Italian reconstruction via the Marshall Plan, thus gaining, in exchange, a strategic place in the Mediterranean. During the Cold War, it became imperative to promote, against the Soviet model, the superiority of the "American way of life" through culture. Cinema, together with other economic and political venues, was an ideal vehicle to achieve such a goal.

In the postwar era, American runaway companies came to Italy to reinvest funds blocked by the Italian government. ${ }^{9}$ Italian state funds and the American dollars turned Cinecittà in the 1950s into "Hollywood on the Tiber”. 10 The first production was Quo Vadis? (Mervyn LeRoy, 1951), an historical epic filmed entirely in Cinecittà. LeRoy's movie was followed by many others, including Ben-Hur (William Wyler, 1959) and Cleopatra (Joseph Mankiewicz, 1963). The historical epic had been an asset of Italian national cinema since the silent era (Cabiria, directed by Giovanni Pastrone, 1914), remaining popular during Fascism, (Scipione l'Africano, directed by Carmine Gallone, 1937) and even after the war (Fabiola, directed by Alessandro Blasetti, 1948). Throughout the 1950s and until 1963, Italian filmmakers realized that they could recycle set materials and found footage left over by American productions, using their inventiveness to create low-budget historical and mythological films. Their commercially oriented creativity gave rise to a genre called peplum. As D'Amelio's article on the mythological epics points out, peplum was an example of transnational cinema, wherein American body builders were hired to play the Hercules/Maciste/Ursus/Sansone protagonist, and contributed greatly to the Americanization of Italian culture, by consolidating the ideal of American superiority (they were after all the winners of World War II), and celebrating over and over the white male hero who, through superior strength, defeats injustice. If we exclude their cinematic roots, the sandal-and-sword epics were less an example of national cinema than of transnational cinema or, more precisely, of a national cinema that "Americanized” itself. Such self-Americanization is also made apparent by the widespread practice of anglicizing cast names, so that the public would believe they were watching a Hollywood production instead of a low-budget Italian film.

\footnotetext{
8 The Alfieri Law was promulgated in 1938, but enforced in 1939. It was not a ban on foreign imports. Rather, imports of foreign films became a state monopoly. As a reaction, the four U.S. major studios (Paramount, MGM, Warner and Fox) withdrew their films from the Italian market until after the end of World War II.

${ }^{9}$ Hollywood Studios were attracted by low filming costs to Cinecittà. Moreover, they could reinvest the revenues from their films shown on the Italian distribution circuit according to the new law provision signed by Giulio Andreotti in 1947. Those funds had to be recouped and spent in Italy. See Frayling 2000, p. 64.

10 See the illuminating article of Elena D'Amelio (2014), “The hybrid star: Steve Reeves, Hercules and the politics of transnational whiteness,” Journal of Italian Cinema \& Media Studies 2: 2, pp. 259-277.
} 
Even though the spaghetti western can be easily associated with the peplum and considered a similar case of American self-colonization, the two popular genres must be kept separate. The peplum's ideological message could be summarized by the famous line from The Leopard, "If we want things to stay as they are, things will have to change," a statement that underlines the conservative message of these sandal films in which the hero routinely rescues people from the bad ruler so that the good ruler can be reinstated. The mythological epic's "filmic formula" is used to favor the status quo, with the hope that the Italians would continue to vote for the party in power (the Christian Democrats) away from any possible leftist persuasion. ${ }^{11}$ The case of the spaghetti western is different. The Italian western is the heir of a more complex vision of the world in which the American hegemonic message gets absorbed, de-constructed and spewed out as something else.

By 1963, Sergio Leone was an experienced assistant-director. As his wife said in an interview, he had a passionate response to Yojimbo by Akira Kurosawa: "You know, the original story of Yojimbo comes from an American novel, and it would be wonderful to take it back to where it originally came from."12 Leone was immediately struck by the idea of turning the samurai film into a western. He worked, as Frayling reports, on the "adaptation", making a transcript of the dialogue of Yojimbo translated from Japanese, in order to be sure not to repeat a single word and, always according to Leone himself, in order to retain only the basic structure of Kurosawa's film. ${ }^{13}$

The history of the gestation of A Fistful of Dollars, the shoestring budget, the fact that his was the second film to be shot with the props left behind by another production—Bullets Don't Argue by Mario Caiano, also filmed in Spain - the tormented search for a protagonist and so forth, is thoroughly documented and does not need to be revamped here. ${ }^{14}$ The movie was released in Italy in August 1964, but was distributed in the United States only in 1967 because Leone's distributer, Jolly Film, "forgot" to secure remake rights and to pay Kurosawa's studio, Toho Film, ten thousand dollars. The litigation went on for years and eventually was resolved in favor of Kurosawa, who earned quite a sum out of A Fistful of Dollars distribution rights in the Far East.

Although starting in the 1960s Hollywood production of westerns decreased, Spain and West Germany had produced some successful films and had built in Tabernas (Almeria, Spain) the sort of Mexican-looking sets from which the spaghetti western would profit a couple of years down the road. Before Leone's A Fistful of Dollars came out, Italians had already made some westerns, but they were sort of B-movies that followed the classic western formula, often characterized by long and repeated sequences of the same riders galloping up and down the same Yugoslavian or Italian canyon, and by poorly scripted stories of vendettas, good versus evil, treasure hunts and so on.

It is common knowledge that, by and large, most of the Italian westerns that followed Leone's A Fistful of Dollars were also co-productions, usually Italian-Spanish-German or Yugoslavian, and Italian directors like Leone himself had to operate in a transnational environment. They were forced to hire actors from different countries, shoot abroad, and often re-dub the soundtracks in various languages. As with the peplum genre, Italian directors preferred to hire American actors in leading roles, and they and the whole cast appeared in the

\footnotetext{
11 See A. Brogi Confronting America. The Cold War between the United States and the Communists in France and Ital. Chapel Hill: North Carolina UP, 2011, and Ellwood D. and Brunetta G. P., eds. Hollywood in Europa: Industria, politica, pubblico del cinema 1945-1960. Firenze: Casa Usher, 1991.

12 See Frayling, 2000, p. 119.

13 See Frayling, 2000, p. 125.

14 See the chapter "Fistful of Dollars" in Frayling, 2000, pp. 118-165. See also Christian Uva in Sergio Leone. Il cinema come favola politica. Roma: Edizioni Fondazione Ente dello Spettacolo, 2013, pp. 112-144.
} 
credits with English pseudonyms so that the movie could be passed off as an American production. In view of the "Anglo-Saxon coating" that was applied to the Italian westerns, one question arises: What is left of the national? Where is the "Italianness", if there is one, of the Italian western? Because Leone is the creator of the Italian western, the one who initiated the cycle that was copied many times over for a decade, we must look at $A$ Fistful of Dollars as a prototype, a movie that when dissected can shed light on the national-transnational dichotomy of the spaghetti western. However, before studying the prototype, we must look at the complex history of the origin of the first spaghetti western, taking into account that A Fistful of Dollars was "transcoded" by Leone from Kurosawa’s Yojimbo (1961) that derived his script from Dashiell Hammett’s Red Harvest (1929).

\section{The Origins: Dashiell Hammett's Red Harvest and Carlo Goldoni’s The Servant of Two Masters}

Red Harvest is the story of an American private detective who, during the Prohibition Era, goes on business to a small mining town in the Midwest (Personville) ruled by criminals. The town is so plagued by corruption that in the novel it is referred to as "Poisonville". ${ }^{15}$ The male protagonist is identified as "the Continental Op" or simply "the Op", because he is an operative employed by a Continental Detective Agency based in San Francisco. The Op arrives in a place where he does not know anybody and nobody knows him; he does not make any friends; and he does not seem to be friendly even with the two fellow operatives from his agency. The reader finds out very little about him in the course of the narration, except that he is a loner and a "man with no name." As soon as he arrives in Personville, he learns that the person who hired him has been assassinated, but he does not leave; instead, he starts fighting corruption and battling crime. The archetypal plot of good versus evil is certainly not a new one, as Northrop Frye reminds us. We are between the detective story and the thriller, between irony and melodrama when "a man-hunter locates a pharmakos and gets rid of him". ${ }^{16}$ According to the critic, the triumph of "moral virtue over villainy" in melodrama implies the idealization of those virtues by the audience. ${ }^{17}$ In the case of Hammett's novel, we deal with a man-hunter who, in his relentless pursuit of justice, makes it difficult for the audience to idealize his quest. As Frye reminds us "we read murder story [gangster story, in this case] with a strong sense of the unreality of the villainy involved." We "regard them as a kind of ironic game". ${ }^{18}$ It is precisely because we do not take these crimes seriously that we, as readers, derive pleasure in these stories. It is indeed difficult for the reader of Hammett's novel to take the protagonist seriously, because he proceeds in his pursuit of reforming a community wracked with violence and unrest in a rather unorthodox way. He stirs things up and turns the bad people loose on each other; to do this, he does not shy from lying and cheating. The old Machiavellian saying, "the end justifies the means," could not be more appropriate for describing his modus operandi. The Op mostly functions outside the boundary of the law: What keeps him from slipping completely into unlawfulness is the fact that he has to respond to his boss, the "Old Man" in San Francisco, who seems to represent some form of law and order to which he eventually has to conform.

\footnotetext{
${ }^{15}$ Red Harvest, by Dashiell Hammett. New York: Avenel Books, 1980. For a critical analysis of Hammett's novels see Beams Falling: the Art of Dashiell Hammett, by Peter Wolfe. Bowling Green: Bowling Green UP, 1980; Reading Early Hammett, by LeRoy Lad Panek. London: MacFarland, 2004; Selected Letters of Dashiell Hammett 1921-1960, by Richard Layman and Julie M. Rivett eds. Washington, D.C.: Counterpoint, 2001; Dashiell Hammett, by Julian Symons. New York: Harcourt Brace Jovanovich, 1985.

${ }^{16}$ See Northrop Frye, Anatomy of Criticism. Princeton: Princeton UP, 1957, pp. 46-47.

17 For Frye the ironic mode is typical of detective stories, but as we move away from the Sherlock Holmes period, the stories become more and more brutal and begin "to merge with the thriller as one of the form of melodrama." In melodrama, the core themes are "the triumph of moral virtue over villainy, and the consequent idealizing of the moral views assumed to be held by the audience" (Ibidem, p. 47).

18 Frye, ibidem, pp. 48-49.
} 
To sum up, the detective is a sort of rogue operative who fights against a society populated by corrupt capitalists, wicked police, crooked politicians, and a variety of gangsters: gamblers, assassins, smugglers, and bootleggers. Along the way he shoots two men in self-defense, but feels no regret, because he acknowledges the necessity of cruelty in his job, even if he, sometimes, feels compassion for those men undone by their human frailty (see the painful death of Reno Starkey). His sympathy, however, is never verbalized and his emotions are never revealed. Only the reader has access to his inner thoughts and emotions through brief glimpses. The private eye is a manipulative, skillful individual, who uses people for what are essentially his ends. He is many things: an agent of justice, a vigilante fueled by a sense of mission and by his own sense of vindication-meaning that the ones who try to do him wrong, such as Chief of Police Noonan, deserve to die, and the private eye makes sure they do. Upon his arrival in town, he starts off by tackling the toughest and smartest opponent (Max Thayler "Whisper"). At first, he clears the gangster of a murder accusation, then he proceeds to frame him for a murder he did not commit.

The Op is not troubled by violence. He accepts it as a natural consequence of the state of things, and he knows he has to play dirty in order to survive. The novel features several killings, but most of them happen "offstage" and are recalled by some of the characters after they have occurred. The novel ends with the hero accomplishing his task without having to have a shoot-out because the last remaining criminals eliminate one another.

To conclude, our hero is a wisecracker, has a peculiar sense of humor and uses his linguistic agility (slang, underworld idioms, colorful insults) as a way to challenge any authority. He sports an attitude, does not speak much, and is rather surgical in his way of communicating with friends and foes alike. Unlike Dinah Brand, the only female character in the novel—a totally mercenary "fallen woman" whose unique goal in life is to pursue money and wealth - the hero is not interested in any monetary acquisition; once the agency fee gets paid, he is satisfied. Morally, the protagonist is more an anti-hero than a hero: He stirs things up and proceeds to consciously ruin people, causing their deaths, and, in so doing, he appears to share some of the rueful qualities of the villains. Toward the end of the novel, however, he realizes that he has been "poisoned by Poisonville", and therefore, to make amends, he passes the baton to one of his colleagues and to the new police force. They will tie up the loose ends, and, hopefully, defeat crime using more orthodox ways.

The title of the novel is symbolic: The Op indeed gets a bloody harvest, and by the time, he is finished with his mission, the town has been painted red by the blood spilled in the streets by the criminal factions destroying one another, thanks to the skillful meddling of the hero. The protagonist is a sort of Grim Reaper, who leaves a trail of blood behind wherever he goes. ${ }^{19}$

\footnotetext{
19 Critics have been wondering why Hammett at the incipit of the novel has the Op meet a character, Bill Quint, who never surfaces again in the story. Bill Quint is a union organizer who gives the Op the "low down” on what happened to Personville. The story recounted by Quint tells how the miners, who in the 1920s demanded better working conditions, obtained them from the owners of the mines, but when the copper business got bad the agreements were eventually revoked, and strikes and bitter struggles ensued, so the bosses called in thugs, and gunmen as strike-breakers. The owners succeeded in breaking the organized labor strife. By the end, the workers' organization was a spent force, but the thugs did not leave town and started to gain power and infiltrate the channels of command, corrupting the institutions. The critics seem to agree that introducing Quint as a speaker in favor of the labor struggle in the beginning of the novel and then making him vanish from the story is somehow a loose end the author did not tie up. The brief encounter does not seem to justify, according to them, the inclusion of this episode as a defense of organized labor against brutal capitalism. Many believe that the episode is a reverberation of a personal experience that Dashiell himself had when he was sent to Anaconda, Montana, in 1917 as a Pinkerton operative to work for the copper mine owners against the striking miners. I, on the other hand, am convinced that Hammett knew very well what he was doing and somehow needed to anchor the central theme of the story, the corruption of a community, on something that could justify the extreme situation in which the Op finds himself in Personville. See Dashiell Hammett, by Julian Symons. New York: Harcourt Brace Jovanovich, 1985, pp. 39-57; Reading Early Hammett, by LeRoy Lad Panek. London: McFarland, 2004, pp. 121-148.
} 
The Servant of Two Masters (1753) is a comedy written by Carlo Goldoni (Venice, 1707-1793) that relies on the commedia dell'arte stock roles. ${ }^{20}$ At the time, playwrights used to write a simple canovaccio (general outline) from which each actor could improvise impromptu with lazzi (word play), pantomime, acrobatic skills etc. Goldoni, instead, writing well-constructed comedies with credible characters set in a realistic environment (usually contemporary Venice), managed to start a theatrical tradition à-la-Molière in Italy, and saved the comedy from becoming stereotyped and confined to the commedia dell'arte routines.

In the Preface to the first edition of The Servant, the playwright calls his work a commedia giocosa (playful comedy), since the "little joke" or "game" of Truffaldino, the servant of the title, constitutes the greater part of it. Goldoni proceeds to inform the reader that his comedy has been purged of all the coarse improprieties of the commedia, and that Truffaldino is a stock character that is both stupid and cunning: "stupid by the things he does without thinking, oblivious to their possible consequences, but extremely cunning, when prompted by self-interest or malice, which is the true character, traditionally, of the peasant." 21 Because Truffaldino is never called with his name in the play, but only referred to as "my servant," a "comedy of error" (waiting tables in two rooms simultaneously, mixing the content of the two masters' trunks) develops among the characters and, as a consequence, the servant succeeds in juggling two masters who are unaware of sharing the services of the same person with various tragicomic outcomes: duels, suicide attempts, confrontations.

Truffaldino (from the Italian truffare, to cheat) carries in the root of his name the trait that distinguishes his character; he is a small-time cheater, he says anything in order to avoid a thrashing by his masters, he lies because he is poor and perpetually in pursuit of food to fill his belly, and he creates people and situations out of his imagination in order to reach his humble goals, a few coins more and a meal. Truffaldino is not the protagonist of the comedy. The protagonists are two couples of lovers. The servant, however, is in many ways the "propeller" of the story, without his selfish machinations the lovers would never meet, the conflicts would never be resolved, and the true identities never discovered.

In spite of the above, it would be hard to claim that Carlo Goldoni's play, The Servant of Two Masters, written in the eighteenth century could have been an inspiration for Leone's first western. The idea of mentioning Goldoni's play might have been a brilliant one for building a defense in the legal contention with Kurosawa's studio, Toho films, but it would be difficult to consider the play anything other than a distant source of inspiration. ${ }^{22}$ Goldoni's servant carries a personality trait that appears throughout Italian cultural history from antiquity (Plautus) to modern times (Comedy Italian Style of the 1960s): the art of getting by. The poor guy who has to use his wits to make ends meet is a classic: He is not bad, but not totally good, and he is a coward who avoids any confrontation. He is often funny and simpatico, but totally unreliable; he is a man of all trades, but not particularly skillful at anything; he avoids hard work as much as possible, relying on his art of getting by to survive. If it is obvious that the servant is indeed alternating between two masters, the two couples

\footnotetext{
20 The characters that Goldoni used in the The Servant of Two Masters-Pantalone/the Venetian merchant, Brighella/the innkeeper, Smeraldina/the maid, Truffaldino/the servant, the Doctor etc.-are all stock characters of the commedia dell'arte. The actors used to wear a particular masks and attires while performing, and each of them was characterized by specific qualities that were well known to the public of the time. Pantalone is the father who is bent in marrying the daughter to a man that she does not love, the Maid is usually cunning and witty, the innkeeper is smart etc. See Carlo Goldoni-Opere, Filippo Zampieri ed. Milano: Ricciardi Editore, 1954.

21 See The Servant of Two Masters, by Carlo Goldoni. London: Nick Hern Books, 2012, pp. xvii-xxviii.

22 See Frayling, 2000, p. 125.
} 
of lovers, he nevertheless is meddling not to destroy them, but to make a living.

It seems that with Goldoni's servant, we are in a zone very distant from the one in which Red Harvest's detective operates. The Op is obsessed by his mission, he is a voluntary dues-ex-machina of destruction, and he is skillful and determined. Both Hammett's novel and Goldoni's play are steeped into the respective national tradition. The first one is a hard-boiled detective story, a literary genre invented by Hammett, Chandler and other American writers who, in the "roaring twenties" and thirties, based their works on gangsters, Prohibition, organized crime and tough-as-nails private eyes and cops. The detective fiction with the gangster movies and the westerns are expressions of a well-defined national identity. Goldoni's body of works also conveys the traditions of his society, seventeenth century Venice, with its social classes, customs and mores. Both Goldoni and Hammett could be grouped under the label of national popular culture. However, the differences between the detective and the servant are striking. The detective is an anti-hero full of courage and determination, while the servant is a sort of Miles Gloriosus without "art nor part" who avoids any conflict; the first lies to achieve his goals, the second lies to get by. ${ }^{23}$ It is evident that the protagonists of Yojimbo and Fistful have a lot more in common with the Op than with Truffaldino.

\section{The Transnational. From America to Japan: Akira Kurosawa's Yojimbo (The Bodyguard)}

Akira Kurosawa (1910-1998) states in interviews that the inspiration for his samurai film, Yojimbo (1961), was Dashiell Hammett's novel Red Harvest. ${ }^{24}$ We are dealing not only with a crossing of national borders, but also with a moving from novel to screen and, consequently, with a form of translation, adaptation, re-writing and permutation. Therefore, first we need to ask ourselves what happened to the American novel when it crossed borders and became a Japanese film. We undoubtedly have a transition from a novel that tells a story on paper to a medium, cinema, that shows the story on the screen, so we face a cinematic transposition of literature. ${ }^{25}$ According to Linda Hutcheon, adaptation is "both an interpretative and a creative act; it is storytelling as both rereading and re-relating." ${ }^{26}$ Adaptation is, therefore, repetition with variation. A transcultural adaptation occurs when a text travels from one culture to another, and often a change of language is involved together with a change of place and/or time period. Akira Kurosawa's Throne of Blood (1957), for instance, is a Japanese film adaptation of Shakespeare's Macbeth; The Magnificent Seven (1960) is a Hollywood remake of Kurosawa's Seven Samurai (1954). ${ }^{27}$ When the original story migrates and is inserted in a different context, in a different society and culture, a change is inevitable, and with it, we have corresponding modifications of the valence or the meaning of the story. In this case, Hutcheon claims, we face a transculturization and indigenization of the text. Kurosawa's film is indeed a clever operation because the detective/gangster story is "lifted" from the American hard-boiled fiction genre and "grafted" onto the Japanese

\footnotetext{
${ }^{23}$ Miles Gloriosus is a comedic play written by Titus Maccius Plautus (c. 254-184 B.C.). The title can be translated as "The Swaggering Soldier" or "Vainglorious Soldier".

${ }^{24}$ In his long career as a filmmaker Kurosawa wrote the majority of his scripts and he also controlled every aspect of his films, including editing. Unfortunately, Red Harvest by Hammett was not credited. See Kurosawa, by Mitsuhiro Yoshimoto. Durham: Duke University Press, 2000, pp. 53-68.

${ }^{25}$ See A Theory of Adaptation by Linda Hutcheon. New York: Routledge, 2006, p. XIV.

26 See Hutcheon, 2006, p. 111.

27 See Hutcheon, 2006, p. 145.
} 
jidaigeki genre (period films/samurai films) very successfully. ${ }^{28}$ This "transfer"-even if the novel is uncredited-allowed the director to create an equivalent in his own culture, succeeding, as a consequence, in making a brilliant transculturization and indigenization of the borrowed material.

Kurosawa's operation is not an adaptation, but a transcoding of Dashiell Hammett's Red Harvest; the director managed to preserve the original, transforming the American gangsters of the 1920s into Japanese gamblers/thugs of the end of the Edo period (1600-1867). From an ideological point of view, Hammett's novel is an implied critique of the corruption of America in the Prohibition Era and a critique of the way in which big capital squashed organized labor. Hammett was writing about his time. Kurosawa's film seems to talk about a distant past, but in fact is a comment on the Japanese society of the 1950s.

In a village plagued by corrupt policemen, government officials, greedy (silk and sake) merchants, gamblers and thugs, arrives one day a wondering samurai (Toshiro Mifune). He has to keep himself afloat in a world with no balance. The old shogunate system of military rulers and feudal lords has collapsed and he has no lord to fight for. He is a wandering soul whose existence is driven by destiny, as exemplified at the beginning of the film by a stick thrown in the air at a crossroads to decide the path to take. However, Kurosawa's film is not about the dissolution of the lord/samurai/feudal system in Japan, but about the crisis of values of a nation that was brought by militarism to the verge of destruction, then, after losing World War II, went through a fast process of modernization, especially during the American occupation (1945-1952), and, in the late 1950s, emerged as a country where old-fashioned values were competing with consumerism and capitalism, and money was becoming the supreme goal. Hammett's critique of America is implied; Kurosawa goes one step further in showing how his characters are driven by greed and how, in turn, greed drives them to destruction.

In Red Harvest, the point of view is only the detective's (the "Op” or the operative); in Yojimbo, the point of view is split between the samurai and the tavern owner, Gonji, who is the moral pole of the story and, from the beginning to the midpoint, counterbalances the supposed amorality of the samurai. In spite of the creation of Gonji, the focus of the film remains, as in the novel, on the protagonist's deeds and vicissitudes until his final victory. Like Hammett's Op, the samurai succeeds in the end, but he is not as lucky as the private eye, because in order to win, he has to face, alone, the last standing clan in a brutal and uneven confrontation that not only involves sword fighting, but even a gun. The Gonji character and the episodes narrating the saving of a woman and her family from the criminal clan, the brutal beating of the samurai, the farmer's son story and the

\footnotetext{
28 The jidaigeki or samurai films were set in the Tokugawa or Edo period between 1600s to 1867. They were fictitious historical narratives set usually in the idealized feudal Japan of the 17th century. The samurai of feudal time followed a code of honor called bushido, under which they protected their lords and committed hara-kiri (self-inflicted disembowelment with a blade) if disgraced or defeated. In the 1950s, jidageiki produced by Toei Studio changed the genre: in these films the hero is a superior sword man who triumphs in the end and kills the villain, the thematic core being the battle between good and evil. However, the fighting scenes are rendered in a ritualistic rather than realistic way. Japanese cinema is often defined in terms of jidageki, or period films, and gendaigeki or modern films. Kurosawa made eleven samurai films, three of which based on original scripts—Seven Samurai, The Hidden Fortress, and Kagemusha; Yojimbo was based on a script that is a transcoding of an American novel; Rashomon, Sanjuro, and Red Beard are adaptations of modern Japanese literary works; The Men Who Tread on the Tiger's Tail is the adaptation of a Kabuki play; Throne of Blood, The Lower Depths and Ran are adaptations of foreign works. The success of Kurosawa's iconoclastic Yojimbo sealed the decline of the Toei samurai production. In the 1960s, following the extreme popularity of Kurosawa's Yojimbo (1961) and Sanjuro (1962), a new type of samurai films emerged. This short-lived (roughly a decade) productions showed extreme graphic violence and fast-paced sword fighting and were thus called zanzoku eiga (cruel film). See Kurosawa by Mitsuhiro Yoshimoto. Durham: Duke University Press, 2000, pp. 54-142; The Flash of Capital-Film and Geopolitics in Japan by Eric Cazdin. Durham: Duke University Press, 2002; The Films of Akira Kurosawa, by Donald Richie. Berkeley: University of California Press, 1996, (in particular, pp. 147-162).
} 
arrival of the government officials do not appear in Hammett's novel; they are creations of Kurosawa. In short, through these added episodes, the filmmaker gives his film a moral center. In Red Harvest, the cynicism of the Op never falters: He is even more cynical and cruel at the end, so much so that he has to leave because he thinks that the town has poisoned him. Whereas Hammett's protagonist remains cynical, the samurai reveals his honesty through his good deeds from the midpoint (i.e. the rescue of the woman) on.

Yojimbo is an action film peppered with bloody sword fights, but it is also a morality play. To this end, Kurosawa frames the story between two events that do not exist in the novel. The first occurs in the initial sequences of the film. The samurai, on his way to the village, meets a farmer who is quarrelling with his son in the countryside, because the young man wants to join a gambling clan; the boy claims that he prefers a life of crime and money to a life of honesty, poverty and hard work. At the end of the film, the samurai spares the young man's life, and warns him to go back to his father's farm, declaring that it is better to live a long life in poverty than a short life in crime. ${ }^{29}$ The emphasis that Kurosawa puts on ethical issues is clear, especially when we consider Gonji's constant nagging of the samurai. The sake vendor repeatedly complains about the ongoing moral decadence of the village and constantly encourages the samurai to leave a place where murder and prevarication rule. When Sanjuro tells Gonji that he is staying because the town is full of men who are better off dead than alive, the vendor assumes that his decision is fueled by greed. Furthermore, the grumpy innkeeper starts to be nice to the samurai only when he discovers that the swordsman has freed the woman from bondage and therefore has proven himself not as greedy and selfish as he might have appeared at first.

In transcoding the original into his samurai film, Kurosawa has preserved the theme of the original story-i.e., the proverbial fight between good and evil—and the main characters. However, he turned the protagonist from a sleuth to a masterless samurai (ronin). The plot order is kept linear in the film as is in the novel. The director, however, does not follow the rule of "adapting by cutting". On the contrary, he proceeds to "adapt by adding” new elements to the story. The incipit and the end are the same as in the original story, but Kurosawa creates the innkeeper character and adds four other episodes from scratch (the woman's rescue, the farmer's son story, the beating of the protagonist, and the bribing of the officials). Kurosawa does not reduce the novel cutting out parts as it is traditionally done; he adds to it, and uses these episodes to prove his point. The saving of the woman leads to the savage torturing of the samurai who refuses to reveal the location of the family he liberated. This episode demonstrates that the protagonist, besides claiming that he is there to cause the clash of the two clans in order to get money for himself is, in reality, a very moral and honest individual who sacrifices himself for the others. In this sense, he is very different from the Op who does not perform any good deeds while dispensing justice.

The division of the novel in chapters is respected by Kurosawa, who separates the various episodes on the screen by using wipes and fades to black, a transition technique that clearly divides the story in distinct parts. The wipes create a theatrical effect, the viewer has the impression of watching a play on stage with curtains closing. On top of that the criminal gangs consist of grotesque individuals that, when confronting one another, step back and forward in a sort of balletic dance, seemingly dominated by the desire to kill and the fear of

\footnotetext{
29 The farmer's son says to his father: "Who wants a long life eating porridge? I want to eat good food, wear nice things. A short, exciting life for me!” At the end, Sanjuro, sparing his life, tells him: “Go home. A long life eating porridge is best!” This dialogue, together with the farmer's exclamation, "Everybody’s after easy money!” reinforces the fact that youth seems to have fallen prey of consumerism, money has become the key to happiness, and happiness seems to be found in goods and not in family relationships.
} 
annihilation. These ritualistic movements give the audience the impression that the hired assassins move like actors on a stage. This theatricality is also emphasized by the fact that the diegetic space consists of a stretch of road inside the village where Gonji's tavern is, and where the houses of the two rival clans sit, at the opposite sides of a rectangular area. Throughout the film, the innkeeper and the samurai observe what goes on in the village through windows and, thanks to the use of deep-focus lenses, the viewer has access to what happens outside as well. The opening and closing of shutters has the effect of curtains, determining the beginning and ending of each sequence.

The samurai uses violence to clean up the corrupt village, selling out his bodyguard skills to one or the other clan in a continuous alternation that triggers havoc; then, he leaves after having "purified" the environment or, as he ironically puts it, when the town is "very quiet", meaning that everybody, with the exception of the sake vendor and the cooper, is dead.

The wisecrack attitude of the Op is also a trait of the samurai's character: He talks very little and never reveals his real name. In the novel, "Op” is short for operative and it is not a real name; in the film, the samurai is nameless, but when asked, he invents a name on the spot and, noticing a field out of the window, he calls himself "thirty-year-old mulberry field" (Sanjuro Kuwabatake). Disguising playfully his own identity is a sign of not taking himself too seriously; for the same reason, he never presents himself as a defender of social justice, he simply does what he does best, sword fighting. Like the detective, the bodyguard sports a sort of black humor: He instructs the cooper to prepare two coffins, then he proceeds to kill two thugs and severs the arm of a third one; finally, after looking back at the latter, he adds "make it three". His comment on the "very quiet town" at the end of the film is also funny and cynical. His friend, the innkeeper, has been wishing to live in a tranquil town since the moment the samurai met him. In the end, amid great devastation, with dead bodies of criminals strewn everywhere in the street and the clan houses on fire, the samurai tells Gonji that now the town is "quiet again," just as he wished.

Turning from telling to showing, music becomes crucial. Instead of period genre music played by traditional Japanese instruments, Kurosawa opted for contemporary modern music, subverting the traditional genre formula. The beautiful soundtrack arranged by the renowned composer and long-time collaborator of Kurosawa, Sato Masaru, utilizes cheerful tunes to accompany the sequences in which the samurai slaughters the thugs, quick and happy marching tempos when the samurai steps into dangerous confrontations, thus creating a contrast between the filmic sequences and the responses that the score elicits in the audience with ironic effects: The juxtaposition of the soundtrack and the wisecracking of the samurai adds a black humor flavor to the film. Kurosawa also introduces repeated sound effects, like the sound of a sword slashing human flesh. The samurai does not use the sword in ritualistic movements. He is swift and violent, limbs are cut and shown on the screen, blood gushes from the wounds. When Sanjuro enters the village, a dog passes by holding in his mouth a human hand, an omen of the carnage that will follow. Even in the final confrontation between Sanjuro and the Ushitora clan the jazzy twangs add suspense to the sequence, but also a certain playfulness. ${ }^{30}$

Yojimbo means bodyguard in Japanese, and the irony is evident even in the title. The samurai pretends to be a bodyguard, and sells himself as such to the clans, but in fact he is the opposite. He does not want to defend the "lords of the village"; he wants to kill them. He cynically and cleverly explains to the sake vendor that in

\footnotetext{
${ }^{30}$ Irony is not only achieved through the dialogue, but also at the iconic level: the samurai has ticks, makes funny faces, walks strangely and some of the characters look cartoonish; at the acoustic level, some sounds like the swooping of a sword cutting through flesh are amplified.
} 
this world, with certain bodyguards around, the employers should watch their back. In re-focusing the themes, the characters and the plot from the page to the screen Kurosawa use a varied range of camera shots. In the first part of the movie, he often uses low-angle medium close-ups of Sanjuro, so the samurai becomes the viewer's focusing point because his upper body occupies the screen. Later on, the filmmaker employs a deep-focus lens and we experience a wider space that encompasses the village, the houses, the street with the characters and, as a result, a whole community, even if a faulty one. In the process, Kurosawa also exploits superbly the compositional possibilities of the wide-screen format (CinemaScope).

In short, the director manages to re-contextualize Red Harvest so successfully that he achieves a form of transculturization. ${ }^{31}$ As Hutcheon reminds us, genres set up audience expectations; as a consequence, choosing to transcode a text into a film has a lot to do with the choice of the genre. The Japanese filmmaker accomplishes the "Japanization" of the hard-boiled fiction, choosing a samurai film instead of a gangster genre like the yakuza, and obtaining, in spite of his choice, enormous success. ${ }^{32}$ If it is undeniable that Hammett's theme is indeed archetypal and universal (good against evil), Kurosawa's operation managed to reset the original story into his own culture, and, at the same time, he innovated the formula of the jidaigeki genre by altering its conventions. He created a cynical, ironic, wisecracking, anti-hero who goes against the rigid formula of the traditional samurai films, does not commit hara-kiri in the end, but results victorious by choosing violence over bushido (the code of honor). Substituting realistic violence with the elegant handling of swords through choreographed movements like in the samurai filmic tradition, the director made the audience realize how artificial the jidaigeki was. Kurosawa's transposition stands on its own, separate from the palimpsest, brings surprise and novelty to the original (variation), and revolutionizes the Japanese filmic period genre, ${ }^{33}$ thus starting off a new samurai filmic trend.

\section{From Japan to Italy: Leone's A Fistful of Dollars (Per un pugno di dollari)}

Eleftheriotis writes that spaghetti westerns are hybrid forms because they are the products of "cultural interaction and exchange" between the American western genre and Italian cinema, between Hollywood and national cinema. We could not agree more with the critic; we need, however, to point out what are the textual specificities of Leone's, first at the level of production, in relation to the industry and the market, national and international, and, then, at the level of aesthetics, in relation to the textual practices that distinguish his film from the American western. Finally, we want to determine what happens to national identity when it gets reworked through the formula of the American genre. ${ }^{34}$ The 1960 s were a moment in which the Italian industry was strong: Domestic films dominated the Italian market, and national attendance was higher than in other European countries (Italy 557 million, UK 215 million, France 200 million, Germany 181 million). The strong American involvement in film production in Italy had allowed the Italian distributers to gain access to the world market, and co-productions accounted in 1964 for 153 out of 270 Italian films. ${ }^{35}$ At the level of aesthetics, we need to keep in mind that, as Hutcheon says, "adaptation is how stories evolve and mutate to fit times and different places ... traveling stories adapt to local cultures just as populations of organisms adapt to

31 See Hutcheon, 2006, pp. 145-159.

32 See Yoshimoto, 2000, p. 289.

33 See Yoshimoto, 2000, p. 245.

34 Cfr. Dimitris Eleftheriotis, “Genre criticism and the spaghetti western” in Popular Cinemas of Europe (London: Continuum, 2001), pp. 92-133.

35 See Eleftheriotis, 2001, pp. 104-105. 
local environments. ${ }^{36}$ In the case of Leone's first film, we have a case of hybridization and permutation; therefore, we need to consider Leone's reworking of Yojimbo as a sui generis endeavor. While Kurosawa embedded Hammett's narrative into an indigenous genre, the samurai film, Leone transferred Sanjuro's story into a foreign genre, the American western. This approach was not a novelty: Kurosawa's The Seven Samurai (1954) had been translated into The Magnificent Seven in 1960 by John Sturges with very fortunate results. ${ }^{37}$ We assume that Leone, a profound connoisseur of American cinema, must have been aware of Sturges' film. Furthermore, as Yoshimoto remarks, the traditional samurai films (jidaigeki) and the western genre had a lot in common: "Both genres, set in important periods of Japanese and American national histories, feature armed heroes - samurai and gamblers, cowboys and gunmen — whose violence plays the essential role in the narrative development and resolution. The western and jidaigeki heroes are often social outsiders who restore order or help people fighting against villains while being fully aware that their virtuous action does not allow them to reintegrate themselves in a renewed social order. And, jidaigeki is not a pure Japanese genre. ${ }^{\text {„3 }}$

Yoshimoto, like Anderson in a 1973 article, affirms that the Hollywood cinema that started a successful cycle in the 1920s with films such as The Mark of Zorro (Fred Niblo, 1920), featuring Douglas Fairbanks as a swashbuckling hero, spawned imitations in the Japanese film industry. ${ }^{39}$ Hollywood filmic conventions, however, were assimilated into Japanese culture and transformed to a point that the samurai films became a Japanese genre. The source of the affinity can be found in the similarities of historical situations in both nations. The western looks at a period of transition in American history mostly between 1860 and 1890 when westbound expansion and the idea of "manifest destiny" were coming to a close. The frontier ceased to exist as such in the 1890s, and the railroad had by then reached the Pacific coast. The same is true for Japan: The samurai films register the crisis of passage from an agrarian society to a modern and urban society, a difficult and transitional moment in Japanese history that took place between the end of the 19th century and the 1950s, even though the samurai films are usually set in feudal times (1185-1867). The similarities between the two genres are emphasized by Anderson when he claims that the jidaigeki like the American western is "a uniquely national film genre that has reinforced a national myth; it has dramatized the nation's fundamentalist code of ethics as nostalgic allegory.,

However, as the critic points out, the action in the samurai films is restricted to small towns and villages, surrounded by farmland. We witness a spatial restriction, the spectacle of vast landscapes, open ranges, green valleys, rocky mountains that connoted the American western have disappeared. ${ }^{41}$ We agree with these points of view, but clearly the comparison between the western and the traditional samurai films holds when we refer to American westerns made before Leone's A Fistful of Dollars (1964) and to the samurai films made before Kurosawa's Yojimbo (1961). If, on the one hand, it is undeniable that Kurosawa altered the conventions thus

36 See Hutcheon, 2006, pp. 176-177.

37 See Yoshimoto, 2000, p. 245.

38 See Yoshimoto, 2000, p. 231.

39 In an interesting article titled "Japanese swordfighters and American gunfighters,” J. L. Anderson writes that the jidaigeki were influenced especially by the silent westerns starring William S. Hart that arrived in Japan around 1920. The critic does not provide any evidence for his claim, but he states that Hart's ruthless skill with a weapon and his fits of violence are similar to the behavior of traditional samurai heroes. Cinema Journal, 12.2 (Spring 1973): 1, p. 2.

40 Anderson 1973, p. 2. The myth would be for America the conquering of the West, for Japan the Tokugawa and Meiji periods during which the shogunate system of military rulers and feudal lords started unraveling.

${ }^{41}$ Anderson J. L., Cinema Journal, 1973, pp. 9-10. There are bits of nature in the samurai films, ponds, cherry blossoms, flowers, but, according to Anderson, these are signs that indicate the emotional states of characters or the mood of the scene. 
uprooting the genre, the same is true for Leone's western. Leone extrapolated the story of Yojimbo, transferred it into the American western, then proceeded to alter the formula, to Mediterraneanize it.

In 1963, after having watched Yojimbo in a Rome theater, Leone started to work at a moviola to translate the dialogue of the film from Japanese into Italian "in order to be sure not to repeat a single word". ${ }^{42}$ Leone claimed that he undressed Kurosawa's characters of their samurai masks and redressed them as cowboys, "to make them cross the ocean and return to their place of origin," in other words, back to the America of Dashiell Hammett. There would be no problem with his statement if A Fistful of Dollars were just a remake of the Japanese film, such as, for example, Last Man Standing (Walter Hill, 1996). ${ }^{43}$ But Leone's film does not fit the bill. Leone took the structure of Yojimbo, transferred it into a foreign genre, and then he went on to modify the basic formula on which that very genre was based. Leone subverted the western formula the same way as Kurosawa subverted the jidageiki, something that Walter Hill's film did not achieve.

A Fistful of Dollars, therefore, is not a remake, but a sophisticated operation in which Leone has Italianized the iconography of the western: at the mise-en-scène level changing the landscape and the look of the hero. At the level of genre, Leone has altered the formula, voiding it of the moral and cultural values that are the foundation of American identity. The Italian director, while keeping the plot line of the Japanese film, has eliminated some events and characters and has altered the relevance of other characters and events, subverting the moral stand of the western formula and the iconography significantly. To a certain extent, Leone has simplified the story line: The merchants affiliated with the criminal clans disappear, together with the more layered structure of Japanese society. The corruption in A Fistful of Dollars is circumscribed to two factions, the liquor smuggler bandits, i.e., the Mexican Rojos brothers (Ramon, Miguel and Esteban), and the Baxters, a family of Yankee gun smugglers whose leader, John Baxter, happens to be the local sheriff. On the other hand, if Yojimbo's Hansuke, the meddling corrupt and greedy officer of the town disappears, in the Italian film the coffin maker Piripero and the saloon keeper Silvanito acquire more screen time and become more relevant from the very beginning. ${ }^{44}$ The cantina owner threatens the Rojos with a gun to save the son of Marisol, Ramon's kept woman, and, at the end, shoots Esteban Rojo to save the gringo's life. Marisol also becomes crucial to the development of the story; in fact, the stranger meets her upon his arrival in town and her liberation sets in motion the brutal beating of the protagonist and his final revenge. ${ }^{45}$

On the whole, the plot remains the same as in Kurosawa's film: A man with no name/stranger/gringo/pistolero (Clint Eastwood) happens along a Mexican village (San Miguel) that looks like a cemetery and is not far from the U.S. border. The stranger comes across a dead body sitting on a horse with a sign saying “Adios, amigo!” He also finds a crazy bell ringer who talks about killing, money and death, and several women dressed in black, before stopping at a well. While drinking, he witnesses a puzzling scene: The

\footnotetext{
42 See Frayling, 2000, pp. 118-125.

43 The film is a gangster story set in the days of Prohibition in the corrupt border town of Jericho, Texas, where two crime syndicates (Italian and Irish) fight each other until, one day, Joe Smith, an "amoral" gunslinger, arrives in town and offers his services to both sides, pitting them against each other. Hill's film is a copycat of Leone's A Fistful of Dollars.

44 The cooper in Yojimbo is a sympathetic character; he helps Gonji, the sake vendor, and the samurai, but he is a bit more ambivalent to the point that when he gets scared, he flees and abandons Gonji who is left alone to carry the canister in which the wounded samurai is hidden. Piripero is more courageous and sides with the gringo from the very beginning of the film.

45 Also in Yojimbo, the rescue of the woman causes the wild beating of the samurai. Although the woman appears only in a short sequence and is not a full-blown character, she is fundamental for the development of the events. In A Fistful of Dollars, she has the same propelling function, but she is given more screen time and is more developed as a character. The cooper (Piripero), the sake vendor (Silvanito) and the woman (Marisol) all become more relevant characters in Leone's film.
} 
beating of a small child and a man by some thugs, while a beautiful woman watches from a window. When the gringo gets into town he is ridiculed by the Baxter's thugs and meets Silvanito, who explains to him why the town looks so lifeless. Like Sanjuro, he is interested in offering his gun for hire to both clans to make money: In order to achieve his ploy, he pits one group against the other.

All the ingredients (story line, characters, happy end), except the mise-en-scène and the weapon of the protagonist, in this case, a six-shooter instead of a sword, have remained the same. However, the elimination of the chance encounter in the opening sequence of the Japanese film between the samurai and the farmer's son alters completely the equation between the two filmic texts. By creating the episode of a son who chooses a life of crime over the hard-working life of his father, Kurosawa shows a critical crux. ${ }^{46}$ The moralizing, almost didactic valence of the episode gives Kurosawa's film a different ideological spin. Kurosawa criticizes the greed brought about by capitalism at the expenses of more traditional moral values. The samurai seems to be interested in making money, but he is even more interested in cleansing the town, and, in order to succeed, he pretends to be selling himself as a bodyguard. The violence of the samurai is justified because it is a moralizing force; he is there, like the Op, as an avenging angel sent to purge the town of men who are better off dead than alive. Kurosawa shares with John Ford a strong ethical sense of what is right and what is wrong. The great classic westerns from Stagecoach to Shane, from High Noon to The Searchers all exhibit this unchallenged sense of justice. There is the good and the bad, and the bad ones are doomed because justice always prevails.

The concern with the evils of modernity remains at the core of Yojimbo, because Kurosawa frames Sanjuro's story inside the departure of the farmer's son from home and the eventual return to his family. In so doing, the Japanese director prevents the destruction of the family unit and reaffirms the validity of the farmer's (and his wife's) values, i.e., hard work, sacrifice and honesty against modern greed. Leone, instead, has accepted modernity and its evils as inevitable; the war against greed and injustice cannot be won on a large scale, but a few battles can be won by some special individuals like the man with no name. Leone's protagonist, while pursuing his capitalistic dream, can correct a few wrongs along the way. Leone's westerns are like adult fables in which injustice can be defeated thanks to the exceptional skills of a man who uses violence to change, momentarily, the world. The Italian western is charged with an anarchic and rebellious force that is missing in the Japanese counterpart.

It is at the ideological level that Leone achieves transculturation. The signs so important in the American western, get stripped of the signified, the mise-en-scène becomes a collection of props, the link between the western and the historical events, the ideological messages, the myth of progress and democracy and the regeneration through violence are stripped away, the archetype of good versus evil remains, but gets redirected; here the hero kills the bad guys because he wants money and because deep down hates a corrupted violent system that can be opposed only with violence. Here is where Leone imbued the film with an outlook that was the result of his era and culture. There is a difference of 20 years between Kurosawa's and Leone's birth. Kurosawa was already an adult during the militarization of Japan that preceded the onset of World War II. A descendant of a samurai family line, he had by 1961 witnessed enough change in Japanese society to realize that something important had been lost during its rapid industrialization and modernization process. His filmography is based, as many critics point out, on the importance of the individual, his moral fiber and his

\footnotetext{
46 At the very end of the movie, Sanjuro meets the farmer's son again, while fighting the Ushitora's clan, and spares his life, sending him home to the farm, claiming that it is better a honest long life eating porridge than a short life of crime.
} 
humanitarian values. ${ }^{47}$ By 1963, Leone was a young man who had survived the Fascist dictatorship and World War II practically unscathed, and after building his career in the 1950s, he was now witnessing the rapid changes of a country that was becoming a modern and industrialized nation following the bleak years of reconstruction. His world was becoming more affluent, but was turning itself into a capitalist jungle with money as the supreme goal, where many of the ideals of the Resistance, such as constructing a more equal and just society for everybody, had been lost.

Leone's jettisoning the farmer's son episode from his film eliminates any ethical pretense. For Leone, San Miguel is a micro-capitalist society where everybody would accept one "boss" as the norm ("Every town has a boss" says the gringo), but in this case, we have one too many bosses and therefore competing economic interests that wreak havoc and destruction. Leone's gunfighter embraces the capitalistic logic. In fact, the gringo sees this situation as a possible source of profit. Unlike the samurai, the stranger does not want to destroy the clans because they are evil: He destroys them to make money, since their destruction will bring him wealth. ${ }^{48}$ However, he does not like prevarication, he hates bullies, and he clearly favors the oppressed. As a result, he uses violence to eliminate the cutthroats. On the one hand, we could consider the gringo an "immoral" individual, and certainly his goal is less noble than the samurai's; on the other hand, he also commits some good deeds: He liberates Marisol and her family, gives them some money, endures torture because of this, and rescues his friend Silvanito. Like the Op and the samurai, he is an avenging angel, but he is an angel with a penchant for gold; by the time he leaves San Miguel, he is a rich man, but he is not so greedy or stupid as to steal the government loot. When the officials arrive to retrieve the stolen gold, he will not be around to answer questions because he will be long gone, leaving the village "nice and clean", but ready to go to the dogs again. ${ }^{49}$

With Yojmbo Kurosawa subverted the conventions of the samurai genre showing realistic violence, negating the bushido code of honor via the happy end, and using modern music in the sound track. Leone subverted a foreign genre by altering the role of violence. In the classic American western, the hero resorts to violence only when there is no other way out (usually relegating the explosion of violence to the showdown at the end of the movie), Leone's anti-heroes resort to violence all the time..$^{50}$ Furthermore, they have made violence into a profession, and they have perfected their weapon skills to a point that they are unbeatable. That is why they are often bounty hunters, or exceptional gunfighters. Unlike the John Wayne-style hero who would never trick the bad guys, the Italian gunmen do not follow such ethical behavior, but tend to use "whatever works" to achieve their

47 See Currents in Japanese Cinema, by Tadao Sato, translated by Gregory Barrett. New York: Kodansha International, 1982, pp. 116-123 and pp. 15-115.

${ }^{48}$ When Consuelo Baxter tells the gringo that he will soon be rich, implying that he seems to be always in the right place at the right time so he can get paid for his deeds, he replies that there is nothing wrong with getting rich. When he gets hired by the Rojos clan, he warns them that he does not "work cheap". If we add to the above what he says to Silvanito, "There is money to be made in a place like this" (i.e. two bosses in competition leave space for a third party to throw a wrench in their doings), it is evident that, unlike the samurai, the man with no name shows a pretty detailed acceptance of how modern society works: professionalism, information, money, competing business. Unlike the samurai, he will leave town with gold in his pocket. Sanjuro leaves after having committed a good deed (liberating the town) as poor as before; the stranger leaves after having committed a good deed (liberating the town and having found the government loot) with lots of money in his pocket. The Op leaves town with no money like Sanjuro.

49 Leone's western films always show a pretty cynical view of the world: There is corruption, greed and a lot of injustice; the moral universe of the classic American western could not be any more distant. In Leone's West, violence does not regenerate anybody, progress and history are manipulated by big capital and government, his protagonists live in a dangerous everlasting "present".

50 See the most famous examples of classic westerns like Shane (George Stevens, 1953) or High Noon (Fred Zinnemann, 1952), in which the showdown occurs usually at the very end of the film. The American westerns continued to be produced into the 1960s, until The Professionals (Richard Brooks, 1966) and The Wild Bunch (Sam Peckinpah, 1969) were released, by then, Leone’s westerns were also shown in the US. See Austin Fisher, Radical Frontiers in the Spaghetti Western (London: I.B. Tauris, 2011), p. 226. 
goal. ${ }^{51}$ While the classic cowboys in most cases were reacting to adverse situations, these new pistoleros are pro-active. They look for violent situations, and they create conflicts; they ceased long ago to think that the world can be changed for the better. They are not on a mission. At most, they think that the ways of the world can be temporarily modified. Basically, they have lost faith in the "progress and a better society" that animated the classic heroes. The Indians have been defeated (in fact, they have disappeared altogether from the Italian screen). Progress has arrived and it does not look that appealing. Justice has not yet been achieved.

The gunslingers in Leone's trilogy are outsiders who have no desire to integrate themselves into society, and who do not particularly like their world, dominated as it is by injustice, violence, and corruption. They have figured out that money is a necessity, and they have accepted the rules of capitalism, but they do not like the way things work. So, as soon as they have a chance, they use violence to undermine the unjust microcosm they inhabit, but they harbor no illusions. Leone's films are indeed "fables for adults" fables, because they reconstruct a mythical land that never existed, but was borrowed by another mythical place, the American western genre, that long before had created a Far West that existed only on screen and had nothing to do with the real geographical or historical entity. These are fables for adults, because in spite of the happy endings, they are pervaded by a sense of pessimism, disillusionment for a world that is what it is and will never change. In this world, especially in Leone’s Duck, You Sucker! (Giù la testa!, Leone, 1971), there is empathy for the oppressed. There is a powerful urge to rebel against the oppressors, the necessity of matching violence with violence. However, the end of Duck, You Sucker! contains a cautionary tale of revolution as a double-edged sword for correcting wrongs.

If ideologically, the cynical world view that transpires from Leone's A Fistful of Dollars can have a direct correlation with the director's own outlook on life because of his Italian upbringing in a country that was undergoing an accelerated process of modernization and industrialization while, at the same time, exhibiting signs of the conflict and contradiction that were soon going to explode during the students' and workers' rebellion of 1968, Leone's lasting contribution to the western has to be found especially in the unusual iconography of his films. Because of budget and production constraints, A Fistful of Dollars was filmed in the Spanish desert area of Almeria where the landscape supposedly recalled Arizona or New Mexico, a setting appropriate for the village of San Miguel as a Mexican border town. ${ }^{22}$ The aridity of the landscape, the Mediterranean architecture that looks like adobe style, the dark features of the characters, especially of the stunt men and the heavies, who were either Spaniards hired on location or Italians, contributed to making the film look like an unusual kind of western. All these factors instead of weighing negatively on the production of the film, helped Leone to colonize the American western through the Mediterraneanization of the mise-en-scène. The protagonist of A Fistful of Dollars wanders into town riding a mule, is unshaven, chews on a cigarillo even when he speaks, thus slurring his diction, and sports a nonchalant attitude that together with his slow movements make him look like a big, dangerous cat, ready to pounce, but otherwise too lazy to do much else. ${ }^{53}$

In colonizing the western genre, Leone also transferred into it Catholic symbols typical of his own culture:

\footnotetext{
51 The stranger does not hesitate to transport the corpses of two dead soldiers from the river bank to a cemetery to provoke a shooting between the Rojos and the Baxters.

52 A Fistful of Dollars was filmed in Almeria, a region of Southern Spain, in the Tabernas Desert, a zone that supposedly resembles the Southwest United States for its windswept plains, aridity, rocky ravines, and dried out riverbeds. Some sequences were also shot near Madrid, in La Pedrizia di Colmenar el Viejo.

53 The man with no name shares some qualities with the Japanese bodyguard: He has a wicked sense of humor, is ironic, looks scruffy and measures his words. If the gringo is unshaven, rides a mule, and keeps a cigarillo stump permanently in his mouth, Sanjuro twitches his shoulders, chews on a toothpick and sports an unusual way of walking that is enhanced by the rhythm of the music.
} 
in A Fistful of Dollars, Yojimbo's little Japanese temple becomes a small church with bells and a bell ringer; the gringo, like a reincarnated avenging angel during the final duel, seems to be crucified in a Christ-like position by the bullets, before undergoing a complete resurrection. The black-and-white photography of the samurai film with the dark Japanese wooden structures and the village road swept by wind and gray dust is transformed into a place where the white of the stucco houses reflects the light of a blinding sun, and bright colors abound everywhere in the sparsely populated village where the dust comes from dynamite explosions.

Three large-scale massacres are presented: two at the Rio Bravo river, one performed with gusto by Ramon Rojo (Gian Maria Volontè) with a machine gun, and the other off screen, which we know of because we see a pile of dead bodies in a wagon; the third is the elimination of the Baxter clan, executed with great pleasure by the Rojos and their henchmen who mow down the surrendering smugglers when they rush out of a house in flames. Leone's protagonist also contributes to the dead body count: He exterminates the thugs at Marisol's house to liberate her, and he kills all the Rojos in the final duel. The episode of the torturing of the gringo is more realistic and much more sadistic than in Yojimbo. Suspense is added to every confrontation by a specific choice of camera shots. A multiplicity of shots/reverse shots, deep-focus shots/close-ups dilate time, provoking anxiety in the viewer. Extreme close ups of the gringo's face, squinting eyes, grinning smile, fingers on the trigger, his gun, his hand, his boots, alternate with extreme close ups of the faces of his opponents, their hands, their eyes... until finally, the hero's six-gun fires a few rounds and the henchmen fall dead. The combination of extreme close-ups together with the musical theme (prolonged twangs of electric guitar) recurring throughout the film and accompanying the protagonist's violent deeds keep the viewer on edge. The soundtrack, arranged by Ennio Morricone, mixes virtuoso whistling, with guitar and choral arrangements by Alessandro Alessandroni, trumpet (deguello-style) by Michele Lacerenza, choir singing by I Cantori Moderni (soprano Edda Dell'Orso) and cracking whips, clinking spurs, and rifle blasts. As Dario Argento stated in an interview about Leone's first film “... This was a western we dreamed of seeing-the historical western was not so inventive, not so crazy, not so stylish, not so violent." ${ }^{54}$

\section{Conclusion}

With A Fistful of Dollars, Leone managed to create a transcultural translation of the Japanese film, a domestication of the American genre, and finally, like Kurosawa, succeeded in giving birth to the spaghetti western, which was neither a spin-off of the American western nor a sub-genre, but a new development of the western genre; afterwards, the American western would never be the same and the classic western would be considered almost defunct. Both filmmakers preserve in their filmic rendition the man-hunter that battles evil at the center of their narration. Both films, in transferring the story from Hammett's novel to the screen, have kept Northrop Frye's archetype intact. The audience enjoys the deeds of the "hero" in his unstoppable path, with one difference: in Yojimbo, Sanjuro is an example of moral virtue we can identify with, while in A Fistful of Dollars, it is more difficult to identify with the stranger because his self-righteousness approaches at times the one of the lynching mob, as Frye suggests.

Eleftheriotis writes that "the Italianness of the spaghetti western does not reside in hidden national cultural references, plots, themes and underlying value system, but in the very ability... to weaken (if not erase) the national as its referent." We disagree with the above statement, because Leone mirrored in his film, the

\footnotetext{
54 See Frayling, 2000, p. 163.
} 
contemporary modern values (the ones of the newly industrialized Italy) together with the reservations, doubts and misgivings that the Economic Miracle brought about, he did not erase the Italian identity, but he projected a modern identity that was no longer specific to Italy, but was becoming common to many western nations. By the time, the 1960s came around, Italy like many European countries was industrialized, consumerism and capitalism were widespread, and faith in the institutions was fading away. This cynical way of looking at the world was not unique anymore. If it is true, that at the iconic level, the disentangling of "the hero of the spaghetti western from the context of the American cultural and historical specificity" creates a place from which the viewer can experience the Wild West without buying into the American myth, it is also true that by that time, very few people in the world were buying into such a myth. In the United States, the civil rights movement showed that the exploitation of minorities and of Native Americans (the celluloid Indians of so many Hollywood productions) had to stop. The rebellion of the minorities spurred a much overdue re-reading of the history of the American frontier that eventually de-mythicized the dream of Manifest Destiny. ${ }^{55}$ The onset of the Vietnam War, the Black Panthers, and the counter culture movement started shaking the general faith in a system that was "working for everybody", showing how the capitalist dream was working only for some, usually the white and the rich. The combination of the distribution on the U.S. market of $A$ Fistful of Dollars in 1967 coincided thus with an international situation in which rebellious tendencies were brewing in Europe as in the United States. The faith in a democracy in which justice always prevails and the institutions are honest was crumbling in many countries.

As Martinez suggests, retold stories "build bridges across cultures and then proceed to burn them while retaining some memory of the connection., ${ }^{56}$ A Fistful of dollars is, therefore, a permutation, a story retold across borders, translated into an indigenous culture, one that produced a new "narrative" despite the presumed connection with what has gone before. The resonance between the spaghetti western and films like The Wild Bunch (Peckinpah, 1969), Two Mules for Sister Sara (Don Siegel, 1970), High Plains Drifter (Eastwood, 1973), The Outlaw Josey Wales (Eastwood, 1976) and the revisionist westerns that followed, is evident.

We could conclude our discourse on A Fistful of Dollars by pointing out that Leone's gunmen also embody the contradictions of postmodern man, somebody who hates wrongs, sees the flaws in the system, but, at the same time, knows that he cannot change it. Leone's protagonists embody multiple facets: They are anarchic and rebellious, they are capitalistic (they cherish money), they are violent when need be, and they do not want to conform because they are outsiders. It is this hybridity that has made them so appealing. Leone's westerns have been crossing borders, going back to America and to Japan, and they have been enormously successful at the box office all over the globe. ${ }^{57}$ Leone with A Fistful of Dollars imported the American model (the western), re-appropriated the translocal (Yojimbo) and transformed it into the local at the level of aesthetics, then proceeded to strip the ideological valence of the model, infusing into it the doubts and cynicism of a society in transition between consumerism and industrialization. The icons of the American western are present

\footnotetext{
55 See Le Frontiere del West edited by Stefano Rosso (Milano: ShaKe Edizioni, 2008) in which various Italian historians re-read critically the myth of the American Frontier, deconstructing Turner's thesis.

${ }^{56}$ Remaking Kurosawa-Translations and Permutations in Global Cinema, D. P. Martinez. New York: Palgrave MacMillan, 2009, p. xix.

57 The polysemic nature of the spaghetti westerns allowed them to appeal to multiple audiences and to cross trans-genre boundaries. It is clear that Leone changed the western in a way that was appreciated by multiple and diverse audiences and that very different viewers found in his filmic stories "something” with which they could identify. A Fistful of Dollars is one of the most successful films ever made moneywise, see charts in Austin Fisher’ Radical Frontiers in the Spaghetti Western. London: Tauris, 2011, Appendix A, pp. 219-222.
} 
in Leone's film. The denotation is clear, all the props are there even if different from the American western, but at the level of connotation, the social and cultural associations linked to the signs have disappeared. They have been deprived of the social context they originally had. It is at the level of discourse in a Foucaltian way that $A$ Fistful of Dollars becomes transnational, because the preferred message among the many encoded in the text creates a particular understanding of the world that was not only Italian, but was becoming globalized. The commercial success of the film in Italy and abroad proves that the viewers at consumption, in decoding the film from their ideological perspectives, took away the preferred meaning.

\section{References}

Anderson, J. L. (1973). Japanese swordfighters and American gunfighters. Cinema Journal, 12(2), 1-2.

Brogi, A. (2011). Confronting America. The Cold War between the United States and the communists in France and Italy. Chapel Hill: North Carolina UP.

Cazdin, E. (2002). The flash of capital-film and geopolitics in Japan. Durham: Duke UP.

D’Amelio, E. (2014). The hybrid star: Steve Reeves, Hercules and the politics of transnational whiteness. Journal of Italian Cinema \& Media Studies, 2(2), 259-277.

Eleftheriotis, D. (2001). Popular cinemas of Europe: Studies of texts, contexts, and frameworks. London: Continuum.

Ellwood, D., \& Brunetta, G. P. (Eds.). (1991). Hollywood in Europa: Industria, politica, pubblico del cinema 1945-1960. Firenze: Casa Usher.

Frayling, C. (1998). Spaghetti Westerns. London: Tauris.

Frayling, C. (2000). Something to do with death. London: Faber and Faber.

Fisher, A. (2011). Radical frontiers in the spaghetti Western. London: Tauris.

Frye, N. (1957). Anatomy of criticism. Princeton: Princeton UP.

Goldoni, C. (2012). The servant of two masters. London: Nick Hern Books.

Hammett, D. (1980). Red harvest. New York: Avenel Books.

Higson, A. (2006). The limiting imagination of national cinema. In E. Ezra and T. Rowden (Eds.), Transnational cinema. New York: Routledge.

Hutcheon, L. (2006). A theory of adaptation. New York: Routledge.

Layman, R., \& Julie, M. R. (Eds.). (2001). Selected letters of Dashiell Hammett 1921-1960. Washington, D.C.: Counterpoint.

Mancini, M. (2012). Spaghetti Western. Piombino: Il Foglio.

Martinez, D. P. (2009). Translations and permutations in global cinema. New York: Palgrave MacMillan.

Panek, L. L. (2004). Reading early Hammett. London: MacFarland.

Richie, D. (1996). The films of Akira Kurosawa. Berkeley: California UP.

Sato, T. (1982). Currents in Japanese Cinema. New York: Kodansha International.

Symons, J. (1985). Dashiell Hammett. New York: Harcourt Brace Jovanovich.

Uva, C. (2013). Sergio Leone. Il cinema come favola politica. Roma: Ente dello Spettacolo.

Wagstaff, C. (1992). A forkful of Westerns: Industry, audiences and the Italian Western. In R. Dyer and G. Vincendau (Eds.), Popular European cinema. London: Routledge.

Wagstaff, C. (1998). Italian genre films in the world market. In G. Nowell-Smith and S. Ricci (Eds.), Hollywood and Europe: Economics, culture, national identity 1945-95. London: British Film Institute.

Wolfe, P. (1980). Beams falling: The art of Dashiell Hammett. Bowling Green: Bowling Green UP.

Yoshimoto, M. (2000). Kurosawa. Durham: Duke UP.

Zampieri, F. (1954). Carlo Goldoni-Opere. Milano: Ricciardi Editore. 